\title{
Vitamin K-Dependent Protein C
}

National Cancer Institute

\section{Source}

National Cancer Institute. Vitamin K-Dependent Protein C. NCI Thesaurus. Code

C102826.

Vitamin K-dependent protein C (461 aa, $\sim 52 \mathrm{kDa}$ ) is encoded by the human PROC gene.

This protein is involved in the degradation of factors Va and VIIIa. 